\title{
The Jesuit Roots of Spanish Naval Education: Juan José Navarro's Translation of Paul Hoste for the Academia de Guardias Marinas
}

\author{
Marcelo Aranda \\ Quarry Lane School in Dublin, California \\ maranda@quarrylane.org
}

\begin{abstract}
From its origins in 1540 to its final expulsion in 1767 , the far-flung Jesuit network of schools and scholars influenced the development of scientific and mathematical pedagogy in the Spanish Empire. The most important of these schools was the Colegio Imperial of Madrid where young noblemen and members of the Spanish court learned mathematics. Therefore, when Juan José Navarro, an early eighteenth-century Spanish naval officer and reformer, began to teach at the newly founded Academia de Guardias Marinas, he translated French Jesuit Paul Hoste's L'Art des armées navales into a Spanish manuscript to serve as the basis of a curriculum on contemporary naval tactics. Navarro's efforts highlight the continuity between the Jesuit science and mathematics of the seventeenth century and the emerging scientific institutions of the Spanish Enlightenment.
\end{abstract}

\section{Key Words}

Paul Hoste - Juan José Navarro - L'Art des armées navales - Jesuit mathematics Spanish naval reform - Spanish Enlightenment - Academia de Guardias Marinas

In the first decades of the eighteenth century as the new Bourbon dynasty took over power in Madrid, Spanish ministers, military leaders, and intellectuals sought the means to revive their empire's influence and power. One of those officials saw the possibility of renewal in a treatise written by the French Jesuit Paul Hoste $\left(165^{2-1700)}\right.$ on the coordinated maneuvering of fleets in action, L'Art des armées navales ou Traité des évolutions navales (The art of naval

(C) MARCELO ARANDA, $2020 \mid$ DOI:10.1163/22141332-00702003

This is an open access article distributed under the terms of the prevailing CC-BY-NC-ND 4.0 license. 
armadas or treatise on naval evolutions). ${ }^{1}$ In 1718 , Juan José Navarro (16871772), observed a Spanish naval defeat at Cape Passaro that sparked a life-long interest in naval reform and education. Navarro was the alferez or third-incommand of the recently founded Academia de Guardias Marinas in Cádiz, then just a few years old. In later years, the Academia became one of the most important institutions involved in the dissemination of scientific knowledge in Enlightenment Spain, but at that time it was a new school dealing with logistical and curricular difficulties. ${ }^{2}$ As he began designing a course on naval tactics and fleet maneuver for midshipmen, Navarro was able to take advantage of a mathematical curriculum designed by Jesuits and a base of mathematical knowledge disseminated through the network of Jesuit colleges in Spain. Among the first fruits of Navarro's labor was a manuscript copy of Hoste's treatise.

When Navarro translated Hoste's text into a Spanish manuscript, he also created watercolor copies of the original printed engravings. Navarro retained most of Hoste's text and visual imagery, but in the process of translating and localizing Hoste's original French text into a format suitable for the Academia de Guardias Marinas, he repurposed a text meant to promote French naval expansion under Louis XIV (r.1643-1715) into an instrument of Spanish imperial reform under the Sun King's grandson, Philip v (r.1700-24). L'Art des armées navales was a seminal text in developing the paradigm of naval tactics dominant until the introduction of aircraft in the mid-twentieth century. While certainly important in the naval history of eighteenth-century Spain, Navarro's translation of Hoste's text it is also significant as an example of the changes and continuities in Spanish scientific culture in the transition from the late seventeenth-century Spanish Baroque into the Spanish Enlightenment. The intellectual connection between Navarro and Jesuit mathematicians both in and outside of Spain was only possible due to the widespread pedagogical influence of the Society of Jesus.

\section{1 Jesuit Mathematics}

Hoste's book was a late expression of the early modern Jesuit interest in applied mathematics. Christopher Clavius (1538-1612), the founder of the Jesuit

1 Archivo del Museo Naval (AMN) MS 611, Juan José Navarro, Tratado de evoluciones navales and Paul Hoste, L'Art des armées navales ou Traité des évolutions navales (Lyon: Anisson and Posuel, 1697).

2 Antonio Lafuente and Manuel Sellés, El Observatorio de Cádiz (1753-1831) (Madrid: Ministerio de Defensa, 1988). 
mathematical tradition was involved in the development of the Gregorian calendar and was one of the last exponents of the Ptolemaic system. ${ }^{3}$ During the development of the Ratio studiorum in the late sixteenth century, Clavius lobbied for the inclusion of mathematics into the Jesuit curriculum. Clavius wished to elevate the status of mathematics as a discipline and to also improve the quality of mathematical instruction in Jesuit colleges. The first clause on mathematics in the Ratio specified the authors to be taught:

Which Authors should be taught, when, to whom:

He should teach the physics students Euclid's Elements in class for around three quarters of an hour. After they have gained some experience with the material for about two months, he should add to this something about geography or the Sphere [of Sacrobosco], or about those things that are usually of interest. And he should do this with Euclid, either on the same day or on alternate days. ${ }^{4}$

In order to provide textbooks for his fellow Jesuit mathematicians, Clavius produced highly renowned commentaries on Euclid's Elements and Sacrobosco's Sphaera. ${ }^{5}$

When Clavius entered the Society of Jesus in 1555, mathematics was considered a lesser intellectual discipline, in part since mathematical demonstrations did not function as Aristotelian syllogisms. ${ }^{6}$ In a syllogism, or a true demonstration "the premises are the proper causes of the conclusion," and the strongest syllogisms were those that directly linked premises and conclusions. Since geometric proofs abstracted quantities and dealt with the general properties of lines and angles, they were not directly related to the physical world, making them less certain as demonstrations. Clavius used different avenues in his campaign to establish mathematics as a science. While he did write Euclid's first problem as a syllogism, this was not altogether successful and instead he emphasized the dignity and utility of mathematics, especially in its use in astronomy, music, mechanics, and perspective. Additionally, the astronomical

3 James M. Lattis, Between Copernicus and Galileo: Christopher Clavius and the Collapse of the Ptolemaic Cosmology (Chicago: University of Chicago Press, 1994).

4 The Ratio studiorum: The Official Plan for Jesuit Education, trans. and ed. Claude Parvur (St. Louis, MO: Institute of Jesuit Sources, 2005), 109-10.

5 Sacrobosco's De sphaera mundi often referred to as the Sphere was a standard cosmographical text from the late medieval period based on Ptolemy's Almagest. The first six books of Euclid's Elements establish the principles of plane geometry. Lattis, Between Copernicus and Galileo, 37-45. See Lattis and Romano for further details about Clavius, his mathematics curriculum and its spread into France.

6 Lattis, Between Copernicus and Galileo, $3^{2-38}$. 
discoveries of the early seventeenth century elevated the status of mathematics, while the use of geometry in cartography, engineering and warfare made mathematical literacy highly practical.

Clavius also trained a number of mathematicians, and while some stayed at the Collegio Romano, others—such as Gregory of St. Vincent (1584-1667) disseminated his curriculum and ideas about mathematics into other Jesuit provinces. ${ }^{7}$ Beginning with schools in Gandía and Messina in 1549 , the Society constructed schools through the Catholic world and by 1640 , approximately five hundred Jesuit schools and missions were active around the world, with a large number of them in Spain and its overseas colonies. ${ }^{8}$

The Colegio Imperial was the most respected of all the Jesuit colleges in Spain, mainly due to its role as a school for young aristocrats and its location in the center of Madrid. ${ }^{9}$ The first Jesuit college in Madrid was established in 1560, but a few years later in 1572, it moved to a location a few blocks away from the Plaza Mayor and it became known as the Colegio de San Isidro. In 1603, it acquired the name of Colegio Imperial due to the endowment given to the school by Empress Maria of Austria (1528-1603) that year.

In 1625, Juan Cedillo Díaz (c.1565-1625), the cosmographer-major of the Council of the Indies, died and without any other replacement available, the Jesuits of the Colegio Imperial were tasked with providing lectures in cosmography, navigation, and instrument use. From shortly after Cedillo's death until July 10, 1628, the Jesuits continued as interim lecturers. On September 10, 1628, another royal decree linked the position of cosmographer-major to one of the mathematics chairs:

7 Lattis, Between Copernicus and Galileo, 24. Gregory of St. Vincent, a Flemish Jesuit returned to the Spanish Netherlands where he taught both ancient languages and mathematics at various schools. Jean-Charles de la Faille, one of his students and a fellow Jesuit, became chair of mathematics and cosmographer general of the Council of the Indies at the Colegio Imperial de Madrid, a position that allowed him to interact with both the royal family and Spanish aristocrats.

8 Marcelo Aranda, "Deciphering the Ignatian Tree: The Catholic Horoscope of the Society of Jesus," in Empires of Knowledge: Scientific Networks in the Early Modern World, ed. Paula Findlen (New York, NY: Routledge, 2019), 106-25.

9 Among the most famous alumni of the Colegio Imperial were the playwright Lope de Vega (1562-1635), and the writers Pedro Calderón de la Barca (160o-81) and Francisco de Quevedo (1580-1645). See José Simon Diaz, Historia del Colegio Imperial de Madrid (Madrid: CSIC, 1952), 24-26. 
Since the chair of Cosmographer-Major of the states and kingdoms of the Indies, and [the Chair] of Architecture that were read in my court are currently vacant due to the death of Doctor Juan de Cedillo, it is my will that until such time as a person expert enough to hold these two chairs is found, that those subjects be read at the Imperial College of the Society of Jesus of this village of Madrid by the religious of that order who are able to do so as part of the general studies otherwise taught at the school. They are charged to lecture each day those lessons that have been taught in the past. The religious who will lecture will be proposed by the Provincial and Rector of said College to my Royal Council of the Indies, so that they can tell me of the candidates, and I can approve them. ${ }^{10}$

Thus, when Claude Richard (1589-1664), a Burgundian Jesuit trained in mathematics appeared in Madrid in the summer of 1629, it would have seemed to members of the Colegio as if divine providence had favored the new school by bringing a gifted mathematician to teach there. By enlisting Richard for the new position at the Colegio Imperial the Spanish crown hoped to address the growing problem of mathematical pedagogy in Spain: there were no mathematically knowledgeable Spaniards who could take the position of cosmographer major.

Over the next approximately 150 years, twenty-three Jesuit mathematicians at the Colegio Imperial taught students, many of whom were nobles or royal officials. ${ }^{11}$ Therefore, when we consider the influence of the Jesuits on the dissemination of mathematical knowledge in the Spanish world we must reflect not only on the Jesuits themselves, but also the broader community they formed with their students and patrons. Previous historians have argued about what constitutes a scientific community. Shapin and Thackeray encouraged historians of science to use prosopography in their research, by which they mean "the investigation of the common background characteristics of a group of actors in history by means of collective study of their lives."12 Such a technique has traditionally been used by sociologists and social historians to link

10 Diaz, Historia del Colegio Imperial, 198-99.

11 Agustín Udías S.J., "Los libros y manuscritos de los profesores de matemáticas del Colegio Imperial de Madrid, 1627-1767," in Archivum historicum Societatis Iesu 74 (2005): 371-450 and "Profesores de matemáticas en los colegios de la Compañía en España, 1620-1767," Archivum historicum Societatis Iesu 79 (2010): 3-27.

12 Steven Shapin and Arnold Thackeray, "Prosopography as a Research Tool in the History of Science: The British Scientific Community, 1700-1900," History of Science 12 (1973): 1-28. 
action and context and to also elicit the impact of actors who left little detailed information about their role in social, economic or political activity. In studying the emergence of the European mathematical community in the late sixteenth century, Westman and Feingold highlighted the shared practices and techniques used by mathematicians in the pursuit of elevating the status of their discipline. ${ }^{13}$ In a similar manner, Findlen has demonstrated the interaction of Italian natural historians with certain texts constituted a scientific community during the same period. ${ }^{14}$

As Shapin and Thackeray have demonstrated, an early modern scientific community consisted of various individuals interacting with each other but who formed three distinct layers of scientific actors. ${ }^{15}$ The first layer is comprised of the so-called "publishing men of science," who created the bulk of scientific books and manuscripts, the typical sources used by historians of science. Another layer might be termed the practical scientific actor: medical men and women, engineers, pilots, and others who used science in their everyday work, but were not interested in academic recognition. Some of these individuals may have participated in intellectual and scientific organizations or disseminated scientific knowledge through informal channels such as correspondence. The third layer contained scientific patrons and aficionados. Examples were aristocrats, politicians or merchants who subsidized scientific publications and enterprises. Taken together, the careers and mathematical works of various Jesuit mathematicians illustrate an example of the "publishing men of science" in a Jesuit mathematical community active in seventeenthcentury Spain. With the combination of their use of the Clavian curriculum and teaching duties at Jesuit schools like the Colegio Imperial, they certainly meet many of the criteria of a scientific community. While we have little information about the other layers of this mathematical community based around the Colegio Imperial, we do have records of both Jean-Charles La Faille and José Zaragoza working with aristocratic students, suggesting the possibility of a larger network of students and patrons interested in the uses of applied mathematics.

13 Robert S. Westman, "The Astronomer's Role in the Sixteenth Century: A Preliminary Study," History of Science 18 (1980): 105-46; Mario Biagioli, "The Social Status of Italian Mathematicians, 1450-16oo," History of Science 27 (March 1989): 41-95; and Mordechai Feingold, The Mathematician's Apprenticeship: Science, Universities and Societies in England, 1560-1640 (Cambridge: Cambridge University Press, 1984).

14 Paula Findlen, "The Formation of a Scientific Community: Natural History in SixteenthCentury Italy," in Natural Particulars: Renaissance Natural Philosophy and the Disciplines, ed. Anthony Grafton and Nancy Siraisi (Cambridge: MIT Press, 1999).

15 Shapin and Thackeray, "Prosopography as a Research Tool," 3. 
After 1628, the Spanish monarchy was increasingly embroiled in conflict both at home and abroad and needed mathematically literate leaders able to plan sieges and construct fortresses. Already engaged in wars in both Flanders and German-speaking lands, over the next twenty-five years, Spain contended with rebellions in Portugal, Catalonia, and the Kingdom of Two Sicilies, piracy in the Americas, and war with France, Sweden, and other states. ${ }^{16}$ As a result, the pressing mathematical problems in the Spanish monarchy during the seventeenth century were not theoretical ones, but instead those related to pedagogy and practical applications. This orientation meant that the Society of Jesus played a dominant role in establishing the norms of the Spanish mathematical community from 1628 until the emergence of other mathematically oriented schools in the early eighteenth century, such as the Academia de Guardias Marinas.

By using a Jesuit mathematical work as one of the core texts at the Academia de Guardias Marinas, Navarro drew on the successful and well-known pedagogical model of the Jesuits to develop a school meant to transform young men into naval officers ready to serve the Spanish crown. Previous historiography on Navarro has focused on his role as a naval commander and political figure due to his role as the Spanish commander at the Battle of Toulon in ${ }^{1744 .} \cdot{ }^{17}$ In contrast, Navarro's actions as a pedagogue and synthesizer of nautical science have often been ignored or regarded as a curiosity. Given the ongoing importance of the Academia de Guardias Marinas as a place of scientific instruction and research later in the eighteenth century, Navarro's role during its early years was perhaps more important than his participation in a tactically inconclusive battle during the War of Jenkin's Ear.

\subsection{L'Art des armées navales}

Born in Pont-de-Veyle in the present-day department of Ain, Paul Hoste attended a Jesuit college as a youth. At the age of seventeen, he entered a local novitiate and eventually became a professed member of the Society of Jesus. ${ }^{18}$

16 Pablo Fernández Albaladejo, La crisis de la Monarquía, vol. 4.: Historia de España, ed. José Fontana y Ramón Villares (Barcelona: Crítica/Marcial Pons, 2009).

17 While arguably a tactical defeat, the Battle of Toulon was an important strategic victory for Spain and France during the War of the Austrian Succession. After this battle Philip v gave Navarro the title of Marqués de la Victoria [marquis of the victory]. See Michael A. Palmer, Command at Sea: Naval Command and Control since the Sixteenth Century (Cambridge, MA: Harvard University Press, 2007), 92-97 for an extensive treatment of the battle from the British side.

18 Larrie D. Ferreiro, "The Aristotelian Heritage in Early Naval Architecture: From the Venice Arsenal to the French Navy, 1500-1700," Theoria 68 (2010): 227-41, at 236. 
By 1685, Hoste was professor of mathematics and hydrography at the École de Gardes de la Marine in Toulon. ${ }^{19}$ While in Toulon, Hoste met Anne-Hilarion de Contenin, Comte de Tourville, and an admiral in the French Navy, who sponsored Hoste's hydrographical experiments. ${ }^{20}$ During the Nine Years' War, Hoste participated in the Battle of La Hogue in 1692. Hoste created a system for the coordinated maneuver of warships that he termed "naval evolutions" that combined Tourville's practical experience, his knowledge of geometry, his observations of the French fleet and a historical analysis of naval battles, By naval evolutions, Hoste meant "the movements made by Fleets, or Squadrons for putting themselves into arrangement, and into a situation for attacking an enemy, defending themselves, or retreating with greatest advantage."21 As European fleets switched from galleons to ships of the line during the seventeenth century, the nature of naval combat also changed.

In earlier centuries, fleets of galleys and galleons normally approached each other in a "line abreast" formation, with allied ships advancing alongside each other. ${ }^{22}$ Once the two fleets entered close-range combat a general mêlée began, with ships trying to board or sink each other as the opportunity presented itself. A recent historian has described these early naval battles as "land battles afloat" with more similarity to contemporary military battles than later naval ones. ${ }^{23}$ This began to change in the mid-sixteenth century, especially among the naval forces of England, France, and the United Provinces, as galleons and later the ship of the line became the core of fleets. Unfortunately, these changes also made fleets much harder for an admiral to use decisively. Sailing vessels

19 Ferreiro, "The Aristotelian Heritage."

20 Paul Hoste, A Treatise on Naval Tactics, trans. J. D. Boswall (Edinburgh: Bell and Bradfute, 1834), ix.

21 Hoste, Naval Tactics, 1.

22 The galley, a primarily oar-driven ship with a shallow draft and with sails as a supplementary means of propulsion was the primary warship type in the Mediterranean for over two thousand years. While in earlier periods galleys attacked enemy warships by either ramming or boarding them, by the seventeenth century, galleys were also often armed with a small number of light artillery pieces. In contrast, galleons were long-range fully rigged sailing vessels that could transit across the Atlantic and carried both a larger amount of cargo and heavier artillery pieces. These two characteristics meant that in Spanish service galleons were often used as combination warship and cargo vessels. Carla Rahn Phillips, Six Galleons for the King of Spain: Imperial Defense in the Early Seventeenth Century (Baltimore: Johns Hopkins University Press, 1992), 33-46.

23 Palmer, Command at Sea, 34. See also John Francis Guilmartin, Gunpowder and Galleys: Changing Technology and Mediterranean Warfare at Sea in the $16^{\text {th }}$ Century (London: Conway Maritime Press, 2003) for examples of galley battles. 
maneuvered on a battlefield much larger than that of oar-driven vessels and the wind also allowed ships to maneuver more freely. As a result, warships would often break formation to engage opponents independently. Additionally, environmental factors, such as obfuscating black-powder clouds and the sheer distance between warships all contributed to a lack of centralized control. This meant that "the participants, even the commanding admirals, evidently had little sense of how [...] battles developed once the action began."24

One attempt to deal with this problem was the introduction of the line ahead formation during the First Anglo-Dutch War. ${ }^{25} \mathrm{~A}$ fleet in line ahead formation organized itself into a line with one ship after another with the admiral in the center. ${ }^{26}$ This allowed warships to concentrate their firepower and maintain cohesion when engaging an enemy force. Unfortunately, this also meant that a fleet could potentially be spread out over miles of ocean, with neither the vanguard nor the rear of the formation able to see each other. ${ }^{27}$

Hoste saw naval evolutions as an answer to the increasingly unmanageable nature of naval fleets in the late seventeenth century:

The art of Naval Evolutions is absolutely necessary, since this art is nothing else than the manner of regulating all movements of a fleet. Without it, a fleet would resemble the Barbarians, who have no knowledge of the art of war, and who do without order all that caprice inspires or that hazard may offer. Without the art of the Evolutions, an Admiral can very imperfectly dispose his fleet. Whether it be to oppose himself opportunely to the enemy, whether it be to break through, cut off, double on, avoid, pursue, or force them to engage. All these things require that the Admiral should control each different part, as the mind acts on the different members of the body. ${ }^{28}$

This system of predetermined maneuvers would also allow an admiral to maintain the integrity of a fleet, whether simply changing formation, dealing with changing weather or taking advantage of sudden tactical opportunities:

\footnotetext{
24 Palmer, Command at Sea, 44.

25 Palmer, Command at Sea, 39-65.

26 Palmer, Command at Sea, 45 .

27 For example, during good weather English warships maintained a half-cable's distance (304 feet) between each other. Therefore, a fleet of just ten warships might be spread out over a mile, and the line of a larger fleet could easily reach seven to eight miles. Palmer, Command at Sea, 52 .

28 Hoste, Naval Tactics, xv.
} 
Without the art of Evolutions, the least change of wind, or any accident, will derange the fleet, no one will any longer know what he can, or what he ought to do, they will be confused, cutting off, and falling on board of one another, and letting slip the most favorable opportunities of gaining the weather gage, or doubling on the enemy; they themselves will be liable to be doubled on, and will lose the advantage of the wind without perceiving it; the best intentioned will not know what to do, and the others will always find something to cover their bad maneuverings. ${ }^{29}$

Throughout the treatise, Hoste also references historical battles that illustrate examples of the maneuvers he discusses. While Hoste did not create the maneuvers in his treatise, it was the first scholarly synthesis of the changes in naval combat over the previous two centuries. As a result, it was not surprising that Navarro chose to translate Hoste's text as part of his efforts at Spanish naval reform.

To make the complex evolutions easily comprehensible, Hoste used geometrical figures and diagrams, a language understood by naval officers with a knowledge of geometry. Although they look relatively simple, Hoste's illustrations convey a great deal of information through a combination of geometric figures and ships. Hoste does not indicate if he produced the original drawings, but many of the copper-plate engravings used for the book have a signature at the bottom, some with the name Bouchet, others with M. Ogler. All of the illustrations are drawn from the perspective of about forty-five degrees. The simpler illustrations merely show the direction of the wind or the illustration of different positions in a line of battle. More complex illustrations show an evolution from start to finish with the position of specific ships in a squadron at each stage of the evolution indicated. In this regard, they are similar to either contemporary military drill manuals or modern dance-step diagrams.

Hoste's treatise was recognized as an important work since the book "furnished clear, simple, and practical rules for naval evolutions, drawn from mathematical principles and embracing this important subject in every variety of theoretical and practical detail."30 The second French edition of the book appeared in $1727 .{ }^{31}$ As the influence of the Society of Jesus continued to wane, Hoste's treatise found an audience in Protestant and Orthodox countries.

\footnotetext{
29 Hoste, Naval Tactics, xv.

30 Hoste, Naval Tactics, v.

31 Paul Hoste, L'art des armées navales, ou Traité des évolutions navales (Lyon: Frères Bruyset, 1727).
} 
In 1743 , the book was translated into Danish and into Swedish, in $175^{2 .{ }^{32}}$ The first English translation by Lt. Christopher O'Bryen appeared in 1762 , although it only consisted of two of the six chapters in Hoste's treatise. ${ }^{33}$ Two years later a Russian edition was produced in St. Petersburg. ${ }^{34}$ Finally in 1834, as the first steam warships entered service with the Royal Navy, Captain J. D. Boswall translated the entire text into English. The major difference in Boswall's edition was a radical change in the composition of the illustrations. The drawings were now from a ninety-degree perspective and the ships were abstracted into figures moving in a two-dimensional plane. Boswall also used contemporary early nineteenth-century ships in the illustrations instead of the late seventeenth-century vessels in Hoste's book. The evolutions in Hoste's treatise continued to be relevant since fleets still needed to coordinate their movements even though steam power now freed ships from the caprice of the wind.

The early eighteenth century was a period of both drastic political change and institutional reform in the Spanish monarchy, sparked by a desire to reclaim the leading role of Spain in Europe. The restructuring of Spain's naval forces and office corps was one of the first steps taken in the larger Bourbon reforms. In that regard, Navarro's translation of Hoste's text makes sense especially given the importance of naval power to an empire with holdings in the Philippines, the Americas, and North Africa.

The far-flung nature of the Spanish monarchy meant that the construction and use of effective naval forces continued to be a pressing concern of the crown throughout the early modern period. Within Europe, galley squadrons based in the Italian Peninsula, Catalonia, and Andalusia protected Spanish territories in the Mediterranean, and galleon squadrons served in a similar capacity in Flanders and the Spanish Atlantic. ${ }^{35}$ Another group of galleons escorted the annual Indies fleets and in the Americas anti-piracy squadrons were

32 Paul Hoste, Søe Evolutioner eller en Orlogs-Flodes Ordener og Bevcegelser..., trans. C. F. L. de Fontenay (Copenhagen, 1743) and Evolutioner til sjös eller Underrättelse huru skieppen, af en örlogs flåtta, hållas uti sin tilbörliga ordning, i anseende til hwarannan, wid alla förefallande tilfällen och rörelser, trans. Christopher Falkengreen (Karlskrona: 1752).

33 Paul Hoste, Naval Evolutions or a System of Sea-discipline (London: W. Johnstone, 1762).

34 Paul Hoste, Iskustvo voennyh flotov..., trans. I. L. Golenischev-Kutuzov (St. Petersburg, 1764).

35 Christopher Storrs, The Resilience of the Spanish Monarchy, 1665-1700 (Oxford: Oxford University Press, 2006), 69-71. 
intermittently active in the Caribbean and the Pacific Ocean. ${ }^{36}$ Unfortunately, during the late seventeenth century, these various naval forces were frequently unable to effectively protect Spanish holdings or project Spanish naval power. A series of major defeats beginning with the 1639 loss to the Dutch at the Battle of the Downs, culminated in the destruction of the major Spanish naval forces early in the War of the Spanish Succession (1701-14). ${ }^{37}$

Generally speaking, we can attribute the failure of Spanish naval forces during the late seventeenth century to three problems. First, there was no unified naval command. Spain did not have a navy, but rather many navies, each funded and operating independently of the others. ${ }^{38}$ This, of course, made consolidation of forces difficult. Second, there was a profound lack of training on the part of both officers and crew. Commanding officers had minimal nautical training and depended on specialists to act as pilots and sailing masters. ${ }^{39} \mathrm{Ad}-$ ditionally, lucrative posts, such as those on the escort ships for the Indies fleet were often sold to the highest bidder, not the most competent or experienced officers. ${ }^{40}$ Crews were also badly trained. Third, the variety of specialized missions imposed on Spanish naval forces including trans-Atlantic convoy escort, galley warfare in the Mediterranean, and fleet combat in northern Europe, dispersed Spanish finances and made innovation difficult. ${ }^{41}$ While the North Atlantic maritime powers of England, France, and the United Provinces increasingly moved towards fleets consisting of ships of the line, warships designed to act as floating batteries and fighting in a line of battle, Spain continued to use galleons and galleys in the first decades of the eighteenth century. ${ }^{42}$

As part of a broader system of political reform, on February 21, 1714, the crown unified the different Spanish naval fleets into one administrative unit

$36 \quad$ Storrs, Resilience of the Spanish Monarchy, 71-73.

37 According to Storrs, the defeat at the Battle of the Downs "doomed Spain to second-, even third-class naval power status." During the reign of Charles II [1660-85], Spanish naval forces were defeated in 1676 in Palermo, and were unable to protect Spanish and allied cities from French naval bombardment (Genoa in 1683, Cádiz in 1686, Barcelona and Alicante both in 1691). Storrs, Resilience of the Spanish Monarchy, 64-65.

38 Lafuente and Selles, Observatorio de Cádiz, 45.

39 Pablo E. Pérez-Mallaína, Spain's Men at Sea: Daily Life on the Indies Fleets in the Sixteenth Century, trans. Carla Rahn Phillips (Baltimore: Johns Hopkins University Press, 1998), 92. Carla Rahn-Phillips, The Treasure of the San José: Death at Sea in the War of the Spanish Succession (Baltimore: Johns Hopkins Press, 2007), 39-41.

41 Storrs, Resilience of the Spanish Monarchy, 75-81.

42 Other Mediterranean naval powers like Venice, the Ottoman Empire and the Knights of Malta also continued to use galley squadrons into the first half of the eighteenth century, since they were useful for amphibious raids and in restricted coastal waters. 
controlled by the intendant general of the navy, an office linked to the position of president of the Casa de Contratación..$^{43}$ Although José Antonio Gaztañeta (1656-1728) and the president of the Council of the Indies, Andrés de Pez (1657-1723), built the fleet that participated in the War of the Quadruple Alliance, significant administrative reforms did not begin until José Patiño (16701736) became intendant general on January $28,1717 \cdot{ }^{44}$ Born in Milan, Patiño was the second son of the veedor general of the army of Milan. ${ }^{45}$ With his elder brother being groomed for military service, Patiño became a Jesuit novice in Milan and later continued his studies in Rome. While Patiño eventually left the Society of Jesus for uncertain reasons, it seems as if he attracted the attention of his superiors during his novitiate. No less a man than the Jesuit superior general Tirso González (1624-1705) visited Patiño and attempted to change his mind about leaving the order. ${ }^{46}$ Upon his return to Milan, Patiño was engaged by the marquis of Lenares to act as his agent in Madrid, and later as a judicial official in Finale. ${ }^{47}$ In 1707, Patiño left Milan for Spain, and in 1711, he became intendent of Extremadura, and later in 1713, he held that same office in Catalonia. Patiño's success in enacting reforms in the recently rebellious province of Catalonia made him a natural choice to "reestablish the navy of the kingdoms of Spain and commerce with the Indies." 48

While Patiño initiated various programs during his time as intendant general of the navy, the most relevant to the subsequent work of Navarro was his role in establishing the Academia de Guardias Marinas. The academia was based on the model of the Compagnie des Gardes de la Marines created by the French minister Jean-Baptiste Colbert (in office, 1661-83) in 1669. ${ }^{49}$ Although that original company was dissolved two years later, three new companies of students were created in 1683 . Their effectiveness as a training ground for naval officers is in doubt, since there were many complaints about the additional

43 Carlos Pérez Fernández-Turégano, Patiño y las reformas de la administración en el reinado de Felipe $v$ (Madrid: Ministerio de Defensa, 2006), go.

44 This is the same Andrés de Pez who commanded the 1693 expedition to survey Pensacola Bay that included Carlos de Sigüenza y Góngora as cosmographer.

45 Fernández-Turégano, Patiño y las reformas, 28. The veedor general is a staff position most analogous to an inspector general.

46 Fernández-Turégano, Patiño y las reformas, 30-31.

47 The marquis of Lenares was the general in command of the army of Lombardy and a former student of José Zaragoza. Fernández-Turégano, Patiño y las reformas, 31.

48 Fernández-Turégano, Patiño y las reformas, 35.

49 Lafuente and Selles, Observatorio de Cádiz, 47. 
training that former gardes de la marine required on beginning active service. ${ }^{50}$

Patiño took a personal interest in the academia and shortly after arriving in Cádiz to begin his duties, he arranged for the acquisition of the campus and composed the school's ordinances. ${ }^{51}$ Writing in 1720 to Andrés de Pez about the state of the academia, Patiño explained the rationale behind the school:

The main goal of the formation, maintenance, and establishment of this Corps, is that the King shall not only acquire an able nobility for his kingdoms, one that can serve within the Navy and Army, adorned with the Sciences and subjects of mathematics such as the rules of discrete quantities, Geometry, Trigonometry, Cosmography, Nautical Science, Maneuver, Military Fortification, the theory of gunnery and naval construction, but also allow those who due to a lack of robustness or inclination, desire to go into a profession other than a military or naval one. An Academy will be built, whose campus will be owned by the Crown, with classrooms large enough to accommodate teaching by masters in each of these subjects in the manner that is most suitable and at the same time to employ and instruct those officers in the exercise of arms, military evolutions, the handling of artillery, dancing and fencing. ${ }^{52}$

Patiño saw mathematical pedagogy as a type of political reform to transform the aristocracy. Accordingly, students needed to prove their status as members of the hidalgo class. ${ }^{53}$ In this regard, the Academia de Guardias Marinas was among the earliest of the Bourbon reforms, alongside the new system of intendants and the abolishment of the fueros (autonomous laws) in Aragon.

The full course of study took five to six years, with students beginning their studies between the ages of twelve and eighteen. The Corps of Guardias Marinas grew rapidly from thirty-six cadets in May of 1717 to 122 students in February of the following year. ${ }^{54}$ Patiño hoped to combine the practical orientation of the British system of naval education with the theoretical aspects of the French one. Unfortunately, Patiño's plan of studies was not a complete success, and there were times in the first years of the academy when there were no

50 Geoffrey Symcox, The Crisis of French Sea Power, 1688-1697: From the guerre d'escadre to the guerre de course (The Hague: Martinus Nijhoff, 1974), 24-27.

51 Lafuente and Selles, Observatorio de Cádiz, 50-53.

52 AMN MS 1181, José Patiño to Andrés de Pez, Article 19.

53 Fernández Turégano, Patiño y las reformas, 99.

54 Fernández Turégano, Patiño y las reformas, 98. 
instructors in naval architecture or gunnery, while there were multiple classes in dance and fencing. ${ }^{55}$ Patiño's desire to improve the level of mathematical instruction at the Academia was a likely impetus for his subsequent patronage and support of Navarro's works on nautical science.

\section{A Unified System of Nautical Science}

Returning to Cadiz sometime in 1719, Navarro continued in his position at the Academia de Guardias Marinas. ${ }^{56}$ Navarro believed that naval reform was necessary for Spain to regain its former political influence and to reap the same economic advantages as the other Atlantic empires:

Our Kingdoms are for the most part surrounded by the seas [...] so the best maxim for us should consist in having a fleet that can protect them and transport their commodities to where they can yield gold [...]. Genoa, England, Holland, and France are mighty kingdoms due to the income their ships have brought and the powerful fleets they have always maintained, allowing them to establish feared and absolute republics and kingdoms. This reflection confirms the ideas that if it is convenient for Spain to have land forces, it is even more important for it to have fleets of warships and galleys that will make it powerful, feared and rich in both seas. ${ }^{57}$

The best means to solve the problem of a weak navy was to have a trained body of mariners who could lead the warships and merchant ships of the Spanish monarchy. To train these men Navarro began a project to create a curriculum of the skills and knowledge required by Spanish naval officers at each stage of their career, which in early documents he referred to as the Escuela de Marina. ${ }^{58}$

In his 1739 letter of application to the Real Academia Española, Navarro states his reasons for beginning this project:

55 Lafuente and Selles, Observatorio de Cádiz, 62.

56 Navarro indicates that he was in Cádiz in 1719, so he must have left Sicily sometime after the battle of Cape Passaro, but before the rest of the Sicilian expeditionary force returned in 1720. See José Vargas Ponce, Varones Ilustres de la Marina Española: Vida de Juan José Navarro, primer Marques de la Victoria (Madrid: Imprenta Real, 1808), 35-37.

57 AMN MS 611, fol. 1.

$5^{8} \quad$ Navarro used this term in the manuscripts he wrote in the $1720 s$. 
I was both aware of and alarmed by the reprehensible disrepair of our nation, where there could not be found even the least of the latest advances in naval matters [...] [there were] only a few books or manuals on navigation, a few small vocabularies, and as many in manuscripts, as in print. Being ambitious, driven and full of incessant desire to know, I resolved to apply myself (with the guidance of geometry and drawing) towards the goal of attempting to circulate the new information that would be of most service to the king and the nation..$^{59}$

Encouraged by Patiño, Navarro collected and synthesized nautical and scientific information from various sources including artisans, mariners, and scholars and began translating important foreign books on nautical matters into Spanish. ${ }^{60}$ Navarro stated that he spoke with

the four best contremaestres (pilots) in the fleet, from whom I collected all the maneuvers they used and which they thought indispensable. I received the information from them in writing and by word of mouth[...] after many months of work Don Patiño dismissed them[...] and it remained for me to determine the principles which lay underneath their practice. ${ }^{61}$

Navarro's desire to combine practical experience and theoretical knowledge is evident here, but perhaps just as important is his need to display his knowledge to the Real Academia and for them to validate his expertise to others. By 1739, Navarro had acquired a great deal of practical experience as both a soldier and a mariner, but little in the way of academic credentials such as a university degree. As mentioned earlier, when Navarro began serving the Spanish crown naval officers were regarded as technical specialists focused on operating vessels. Like other emerging early modern experts, Navarro had to prove that not only that he knew how to do specialized technical activities, but also that he knew the fundamental and theoretical principles underlying those tasks. ${ }^{62}$ Since there were no learned societies like the Royal Society or the Royal Academy in the early eighteenth-century Spanish world, Navarro sought approval from the closest local analogue, the Real Academia. After 1750, with the return

59 Application Letter to RAE, in Vargas y Ponce, Varones Ilustres de la Marina Española, $382-83$.

6o Vargas y Ponce, Varones Ilustres de la Marina Española, 383 .

61 Vargas y Ponce, Varones Ilustres de la Marina Española, 387.

62 Eric H. Ashe, "Expertise and the Early Modern State," Osiris 25, no. 1 (2010): 1-24, at 4-11. 
of the Franco-Spanish geodesic expedition from South America, the Academia de Guardias Marinas and other organizations, such as the Real Jardín Botánico (royal botanical garden) would begin to emerge as centers of scientific community.

\subsection{Tratado de evoluciones navales}

Ultimately, the resulting body of manuscripts became the repository and expression of the knowledge Navarro collected over the course of his naval career. In 1723, Navarro finished his first manuscript, Tratado de evoluciones navales (Treatise on naval evolutions) a translation of a 1696 treatise on naval maneuvers and tactics. Although Navarro's translation of Hoste's L'Art des armées navales was the first manuscript he produced, he envisioned it as the third volume of his larger Escuela de marina. ${ }^{63}$ The 1723 Spanish text closely translates the French one, and in the preface to his translation, Navarro states that he tried to leave the original treatise intact. ${ }^{64}$ In later versions of the manuscript, Navarro may have included material from other authors, since in his letter to the Real Academia Española he indicates that he began reading other French writers on nautical matters. By 1739, Navarro's shifted his priorities from accurately transmitting Hoste's ideas to creating a system of flag signals that would be easily understood in the midst of battle.

In transforming the original copper-plate engravings into watercolor illustrations, Navarro maintained the same composition as in the original source material. The two exceptions in Navarro's drawings are his replacement of square frames with round ones (perhaps to suggest the view through a spyglass?) and his use of color, while the original engravings were in black and white. The original engravings had a visual efficiency difficult to surpass, and Navarro likely saw no reason to alter their design.

Given the amount of labor involved in producing this manuscript and Navarro's stated goal of disseminating the latest advances in nautical science to a Spanish audience, it is perhaps surprising that his translation of Hoste was never printed during his lifetime. Navarro's production of these manuscripts might be interpreted as a display of artistic virtuosity to impress the Spanish crown, his patron, perhaps hoping that they would fund its subsequent printing. But even as manuscripts, texts like Navarro's Tratado still served a valuable pedagogical function at the Academia de Guardias Marinas and as a tool of command on Spanish warships. Cadets and subordinate naval officers might learn to maneuver a vessel in a line of battle by making a brief sketch of

63 AMN MS 600, 1.

64 AMN MS 611, 1. 
Navarro's illustrations and copying the necessary instructions for an evolution, in essence producing a nautical commonplace book. Additionally, during this period, it was a common practice for the commander of a squadron or a fleet to circulate an additional set of instructions or signals to his subordinates. ${ }^{65}$ Through these two methods Navarro may have circulated his ideas to his fellow officers, who most needed to learn and apply that knowledge to the task of increasing Spain's naval power.

\section{$4 \quad$ Conclusions}

In his work on the spatial and cultural history of nineteenth-century Rio de Janeiro, Zephyr Frank used the concept of "layers, flows and intersections" to explain how distinct social and economic networks could often intersect with each other in unexpected and contingent ways. ${ }^{66}$ In early eighteenth-century Spain, the social networks of Jesuit mathematicians, Spanish imperial reformers, and naval officers would at first glance seem like distinct layers. When we think of the Spanish Jesuits as part of a larger scientific community, it is possible to show the linkage between the mathematical traditions of Clavius, the Colegio Imperial, Hoste, and a Jesuit student like Patiño who then functioned as a political patron and mentor to someone like Navarro.

Navarro is a liminal figure standing on that ill-defined border between the late Baroque period and the Enlightenment in the Spanish context. Although best remembered for his role in the Battle of Toulon, Navarro probably played a more significant role in early Enlightenment Spain as a conduit for mathematical knowledge to naval officers and as a synthesizer of recent developments in nautical science. Standing between Jesuit science of the seventeenth- and eighteenth-century navy, to some extent Navarro was not part of either world. While Navarro was trying to systematize artisanal knowledge and seamanship into a science, he also acted as a courtier with José Patiño and three successive kings of Spain. Additionally, although he had a great deal of interest in using scientific knowledge to revive Spanish imperial fortunes, he did not have a similar interest in broader scientific knowledge or problems. In this regard,

65 Palmer, Command at Sea, 97. Edward Vernon, commander of the British fleet that attacked Cartagena during the War of Jenkin's Ear, is one example of such an admiral.

66 Zephyr Frank, "Layers, Flows and Intersections: Jeronymo Jose de Mello and Artisan Life in Rio de Janeiro, 1840s-188os," Journal of Social History 41, no. 2 (Winter 2007): 307-28. 
Navarro was very different from later Spanish naval officers who combined scientific pursuits with their naval careers. ${ }^{67}$

The case of Navarro also indicates that there may be more continuity between the Jesuit science and mathematics of the seventeenth century and the Spanish Enlightenment then was previously acknowledged. Navarro's translation of L'Art des armées navales demonstrates an obvious connection to the Society of Jesus. Navarro's attempt at a comprehensive collection of nautical knowledge resonates with similar attempts by Jesuits to create synthetic works of scientific knowledge. While the geodesic expedition of 1735 represents a crucial moment in sparking Spanish scientific engagement (or perhaps reengagement) with the Americas and the rest of Europe, scientific actors such as Navarro prepared the soil for the subsequent explosion of Spanish scientific activity in the latter half of the eighteenth century.

67 Examples of naval scientists from later in the eighteenth century include Jorge Juan, Antonio de Ulloa, Vicente Tofiño, José de Mazarredo, and Alejandro Malaspina. Juan and Ulloa were part of the Franco-Spanish Geodesic expedition that determined the true shape of the Earth. Tofiño was an astronomer in addition to his duties as commandant of the Academia de Guardias Marinas. Mazarredo conducted a hydrographic survey of the Spanish coastline and later was a fleet commander during the Napoleonic wars. Finally, Malaspina circumnavigated the world and led a scientific expedition around the Pacific Rim from 1789 to 1794 . 